\title{
Performance and economic analysis of the production of Nile tilapia submitted to different feeding management
}

\section{Desempenho produtivo e análise econômica da produção de tilápia- do-nilo submetida a diferentes manejos alimentares}

\author{
Érica Bevitorio Passinato ${ }^{1}$; Francisco Oliveira de Magalhães Junior²; \\ Filipe dos Santos Cipriano ${ }^{3}$; Ricardo Henrique Bastos de Souza ${ }^{4}$; \\ Kauana Santos de Lima ${ }^{5}$ Jorge Chiapetti ${ }^{6}$; Luís Gustavo Tavares Braga ${ }^{6 *}$
}

\begin{abstract}
The productive performance and the variable cost of production were evaluated for different feeding strategies for tilapia during the production cycle. A sample of 2,000 juvenile tilapia was distributed $(23.55 \pm 2.38 \mathrm{~g})$ into five treatments and with four repetitions as follows: $\mathrm{C}$ (feed consumption to apparent satiety), R20 (beginning feed restriction when fish reached an average weight of $20 \mathrm{~g}$ ), R200 (beginning feed restriction when fish reached an average weight of $200 \mathrm{~g}$ ), R400 (beginning feed restriction when fish reached an average weight of $400 \mathrm{~g}$ ) and R600 (beginning feed restriction when fish reached an average weight of $600 \mathrm{~g}$ ). The fish were given extruded commercial feed containing $34 \%$ crude protein until they reached a weight of $200 \mathrm{~g}$, at which time they received feed containing $32 \%$ crude protein. Monthly biometrics were performed in order to determine the food restriction starting point, which was one day of restriction followed by six feeding days. The following parameters were evaluated: water quality, productive performance variables, the variable costs of production and excreted nitrogen. The results were subjected to analysis of variance, and the means were compared using Tukey's test (5\% significance). No statistical differences were observed in final weight, weight gain, feed consumption, feed conversion or survival. The fish from the R20 treatment had the lowest variable cost of production ( $\mathrm{g} \mathrm{fish}^{-1}$ ) and the lowest nitrogen excretion into the water. This suggests that feed restriction from the early stages of life does not compromise the productive performance and contributes to reducing the variable costs and the quantity of nitrogen excreted into the environment. Thus, a one-day per week feed restriction strategy can be applied from the earliest stages of life without compromising the productive performance or body composition of Nile tilapia. This strategy can also reduce variable costs of production by means of reducing relative labour and feed costs.
\end{abstract}

Key words: Compensatory growth, Oreochromis niloticus, feed restriction, economic viability

\section{Resumo}

Foi avaliado o desempenho produtivo e o custo de produção variável da utilização de diferentes estratégias de alimentação para tilápia durante o ciclo de produção. Foram distribuídos 2000 juvenis

\footnotetext{
${ }^{1}$ Mestrado em Ciência Animal, Universidade Estadual de Santa Cruz, UESC, Ilhéus, BA, Brasil. E-mail: erica.passinato@ hotmail.com

2 Discente de Doutorado em Ciência Animal, UESC, Ilhéus, BA, Brasil. E-mail: jr.oliveira@zootecnista.com.br

${ }^{3}$ Discente de Doutorado em Zootecnia, Universidade Federal de Minas Gerais, UFMG, Belo Horizonte, MG, Brasil. E-mail: filipecipriano@hotmail.com

${ }^{4}$ Prof., Universidade Federal de Rondônia, UFRO, Presidente Médici, RO, Brasil. E-mail: rick.pesca@hotmail.com

5 Discente de Doutorado em Zootecnia, Universidade Federal da Bahia, UFBA, Salvador, BA, Brasil. E-mail: kslima@ymail.com

${ }^{6}$ Profs., UESC, DCAA, BA, Brasil. E-mail: jorgechiapetti@gmail.com; lgtbraga@gmail.com

* Author for correspondence
} 
$(23,55 \pm 2,38 \mathrm{~g})$ em cinco tratamentos e quatro repetições: $\mathrm{C}$ (consumo até a saciedade aparente), R20 (início da restrição quando peixes atingiam peso médio de 20 g), R200 (início da restrição quando peixes atingiam peso médio de $200 \mathrm{~g}$ ), R400 (início da restrição quando peixes atingiam peso médio de $400 \mathrm{~g}$ ) e R600 (início da restrição quando peixes atingiam peso médio de $600 \mathrm{~g}$ ). Os peixes foram alimentados com ração comercial extrusada com 34\% de proteína bruta até atingirem $200 \mathrm{~g}$, quando passaram a receber ração contendo $32 \%$ de proteína bruta. Foram realizadas biometrias mensais para determinação do início da restrição alimentar, que foi de um dia de restrição seguido de seis dias de alimentação. Foram avaliados os parâmetros de qualidade da água, variáveis de desempenho produtivo, os custos variáveis de produção e o nitrogênio excretado. Os resultados obtidos foram submetidos à análise de variância e as médias foram comparadas pelo teste Tukey (5\%). Não foram verificadas diferenças estatísticas no peso final, ganho de peso, consumo de ração, conversão alimentar e sobrevivência. Os peixes do tratamento R20 apresentaram o menor custo variável de produção ( $\mathrm{g}$ peixe ${ }^{-1}$ ) e a menor excreção de nitrogênio na água, sugerindo que a restrição alimentar desde as primeiras fases de vida não compromete o desempenho produtivo e contribui para a redução nos custos variáveis e na excreção de nitrogênio no ambiente. Assim, a restrição alimentar de um dia na semana pode ser empregada, sem que haja prejuízos no desempenho produtivo e composição corporal dos peixes, além de contribuir para a redução dos custos variáveis de produção, através da redução dos custos relativos à ração e mão-deobra.

Palavras-chave: Crescimento compensatório, Oreochromis niloticus, restrição alimentar, viabilidade econômica

\section{Introduction}

The Nile tilapia (Oreochromis niloticus) is currently a fish species of significant interest due to its desirable characteristics, such as rapid growth and hardiness in addition to its high performance in intensive cultivation systems (FURUYA et al., 2008). However, to achieve successful cultivation in intensive systems, it is necessary to provide the fish with suitable nutrition based on feed formulations that meet their requirements. This strategy enables better use and productivity, while not negatively impacting the production costs because the expenditure may represent $70 \%$ of the costs in such a system (GUIMARÃES et al., 2008).

It is important to note that in addition to suitable nutrition, the frequency with which the feed is offered is also important. This will influence the growth, survival and fillet composition (DAVIES et al., 2006), and savings can be made when the feed is provided at an optimal frequency. Thus, overfeeding represents economic waste, in addition to having a negative effect on water quality due to leaching of the nutrients. Leftover feed, along with faeces, are the main sources of waste in effluents from fish farms, which when associated with metabolic by- products can cause eutrophication of water bodies (TACON; FORSTER, 2003).

Among the feeding strategies that have been adopted in fish, feed deprivation followed by refeeding has excelled. This strategy promotes compensatory growth, which involves a phase of accelerated growth resulting from an appropriate refeeding of the fish after a period of feed deprivation or after being subjected to adverse conditions, such as low temperatures, hypoxia and reproductive efforts (ALI et al., 2003). The response to feed restriction is species specific and depends on the duration and severity of the process, which are more effective when they are applied over a short time period (TIAN; QIN, 2004).

Understanding the physiological process/ mechanism controlling the metabolism enabling the fish to change their growth rate (which is designed to make up for low weight gain during feed shortage periods) is the stimulus for studying food restriction practices and their application potential in fish farming management. Thus, compensatory growth can be used as a tool to maximize growth (ZHU et al., 2005), improve feed utilization efficiency (WANG et al., 2000) and reduce variations in fish sizes 
(ALI et al., 2003) while improving water quality and reducing labour and feed costs (BLANQUET; OLIVA-TELES, 2010).

Thus, the objective of this study was to assess the influence of food restriction on the productive performance and body composition of Nile tilapia. In addition an economic analysis was carried out to assess whether such management was effective in reducing the cost of production and in decreasing pollutant emissions in the environment, which cause a deterioration in the water quality and the final product.

\section{Material and Methods}

All procedures involving animals were approved by the Ethics Commission in the Use of Animals - CEUA/UESC (No. 024/2012). The experiment was performed at the Fazendas Reunidas Vale do Juliana, located in the city of Ituberá, Bahia $\left(13^{\circ}\right.$ $43^{\prime} 56^{\prime \prime} \mathrm{S}, 39^{\circ} 08^{\prime} 57^{\prime \prime} \mathrm{W}$; $48.8 \mathrm{~m}$ altitude) from June 2012 to March 2013.

A sample of 2,000 masculinized, juvenile Nile tilapia with a mean starting weight of $23.55 \pm 2.38$ $\mathrm{g}$ were used for the experiment. The fish were distributed in 20 one-metrenet tanks ${ }^{3}$ at a density of $100 \mathrm{fish} / \mathrm{tank}$, in a completely randomized design, with five treatments and four repetitions, which were divided as follows: C - control, feed consumption to apparent satiety, R20 - beginning feed restriction when fish reached a mean weight of $20 \mathrm{~g}, \mathrm{R} 200$ - beginning feed restriction when fish reached a mean weight of $200 \mathrm{~g}, \mathrm{R} 400$ - beginning feed restriction when fish reached a mean weight of $400 \mathrm{~g}$ and R600 - beginning feed restriction when fish reached a mean weight of $600 \mathrm{~g}$.

The feeding period was six feeding days followed by one restriction day always on a Sunday. During the feeding days, extruded commercial feed containing 34\% crude protein (CP) (4-6 mm in diameter) was provided three times a day until the fish reached a mean weight of $200 \mathrm{~g}$ (biometric
B5). From this point on, the fish were fed ( $8 \mathrm{~mm}$ in diameter) with $32 \% \mathrm{CP}$ twice a day until the end of the experiment (Table 1). The feeding (except for the restriction days) was performed until the fish appeared satiated.

Table 1. Bromatological composition of the feed provided to commercial Nile tilapia subjected to different feeding strategies.

\begin{tabular}{lcc}
\hline & \multicolumn{2}{c}{ Feed } \\
\cline { 2 - 3 } & $32 \% \mathrm{CP}$ & $34 \% \mathrm{CP}$ \\
\hline Dry matter (\%) & 91.30 & 91.88 \\
Mineral matter (\%) & 0.99 & 0.98 \\
Ether extract (\%) & 18.51 & 19.77 \\
Gross energy (kcal/kg) & 4224 & 4203 \\
Crude fibre (\%) & 5.00 & 5.00 \\
\hline
\end{tabular}

Biometrics were performed every 30 days, totalling nine biometrics, including time periods from the beginning of food restriction, once initiated, and continued until the end of the experiment. Thus, the days in which the first, fifth, sixth and seventh biometrics were performed, the fish from treatments R20, R200, R400 and R600 began their feed restriction, respectively.

Fish specimens were collected at the beginning (10 specimens) and the end of the experiment (8 specimens/experimental unit). Fish filleting was also performed at two different times: first when the fish reached a mean weight of $200 \mathrm{~g}$ (F1) and the second at the end of the experiment (F2), according to the change in feed between the two phases.

The samples were frozen and stored at $-20{ }^{\circ} \mathrm{C}$ and subsequently ground and homogenized so as to determine the dry matter in an oven at $105{ }^{\circ} \mathrm{C}$, until a constant weight was achieved, the mineral matter in a muffle furnace at $550{ }^{\circ} \mathrm{C}$, until a constant weight was achieved, gross energy (IKA C200 calorimeter bomb), crude protein (Kjeldahl method) and ether extract (Goldfish method) following the methodology as described by the AOAC (2000). 
At the end of the experiment, the leftover feed was weighed and final biometrics performed in order to evaluate fish growth and weight gain, in addition to the economic analysis. Using the data obtained during the initial and final biometrics, the following productive performance parameters were calculated:

Weight gain $\left(\mathrm{g}\right.$ fish $\left.{ }^{-1}\right)=($ final weight - initial weight)

Daily weight gain $\left(\mathrm{g}\right.$ day $\left.{ }^{-1}\right)=[($ final weight initial weight)/experimental period]

Average feed consumption $\left(\mathrm{g} \mathrm{fish}^{-1}\right)(\mathrm{AFC})=$ (total consumption/no. fish)

Average daily feed consumption $\left(\mathrm{g}^{-1}\right.$ day $)=$ (AFC/experimental period)

Feed consumption $=($ feed consumption $/$ weight gain) Survival $(\%)=[($ Final No. animals/initial No. animals) $\mathrm{x} 100]$

Fillet yield $(\%)=[($ fillet weight/fish weight $) \times 100]$

Protein retention rate $(\%)=[100 \mathrm{x}$ (final body protein - initial body protein)/protein consumption (dry matter)]

Protein efficiency ratio $(\%)($ PER $)=($ weight gain/protein consumed)

Throughout the experimental period (weekly), the temperature and dissolved oxygen in the water were monitored by means of a gauge with a multiparameter probe (YSI Proplus). With the nitrogen values obtained in the initial sample, the carcass and the feed, the following parameters were calculated:

Consumed nitrogen $(\mathrm{kg})(\mathrm{CN})=(\mathrm{N}$ feed $34 \%$ $\mathrm{CP}+\mathrm{N}$ feed $32 \% \mathrm{CP}$ )

Incorporated nitrogen in the carcass $(\mathrm{kg})(\mathrm{ICN})=$ ( $\mathrm{N}$ initial sample $-\mathrm{N}$ carcass)

Excreted nitrogen $(\mathrm{kg})(\mathrm{EN})=(\mathrm{CN}-\mathrm{ICN})$

Incorporated nitrogen $(\%)=(\mathrm{ICN} / \mathrm{CN}) \times 100$

Incorporated nitrogen efficiency $(\%)=100-[(\mathrm{EN} /$ $\mathrm{CN}) \times 100]$
Economic analysis was performed in order to determine the production costs. These were calculated using two main components, represented by direct materials (inputs) and direct labour. In order to calculate the labour, the time spent working, preparing and delivering the feed in each experiment was taken into account. The worker's wage was calculated based on the minimum wage (R \$724.00) as it was in 2014, plus the taxes and earnings informed by the Brazilian Social Welfare and Pension Fund. A value of 290 monthly working hours was used as the base, with the time worked on normal days estimated at a value of $\mathrm{R} \$ 5.56$ per hour and any overtime (Sundays) being paid at doubletime (R\$11.12). For the feed cost calculations, the price of the feed containing 34\% CP was $\mathrm{R} \$ 1.88$ $\mathrm{kg}^{-1}$ and that containing $32 \% \mathrm{CP}$ was $\mathrm{R} \$ 1.54 \mathrm{~kg}^{-1}$. In order to obtain the fillet production costs, only the variable costs were considered because they directly depend on the production volume and can be precisely measured. The production volume (quantity of surviving fish per tank and weight gain) was standardized using the variable cost per gram of fish as the unit of analysis.

The data were subjected to analysis of variance, and when significant differences between the variables were detected, these were subjected to Tukey's test, at a 5\% probability level, using R Core Team (2011) statistical software.

\section{Results and Discussion}

The temperature was maintained between 25 and $28^{\circ} \mathrm{C}$ as was the dissolved oxygen in the water, with values from 4.3 to $6.2 \mathrm{mg} \mathrm{L}^{-1}$. These values are within the range that is considered suitable for ideal Nile tilapia development, which must be between 25 and $32{ }^{\circ} \mathrm{C}$ (CHERVINSKI, 1982) and above 4.0 $\mathrm{mg} \mathrm{L}^{-1}$ for the dissolved oxygen (KUBITZA, 2000).

Different factors may influence the compensatory gain of fish subjected to food restriction. Among these are the different applied protocols, the physiological variation between species, the stage 
of development of the fish when the feed restriction is established, the age of sexual maturity and the refeeding protocol used (ALI et al., 2003). The fish subjected to food restriction (regardless of when it was initiated) had a similar final weight $(\mathrm{P}>0.05)$ as the fish in the control treatment, which were continuously fed (Table 2). Similarly, there were no significant differences observed between the groups in weight gain, daily weight gain, feed consumption, daily feed consumption, feed conversion or survival parameters. These results provide evidence of the occurrence of total compensatory growth. For example, the fish from the R20, R200, R400 and R600 treatments (despite going through food restriction periods) were able to achieve the same final weight as the fish from the control treatment (whose feed was not restricted). In spite of the fact that some fish went through restriction periods whilst still in their juvenile phase (R20), there was no productive performance impairment, because the period in which they were deprived of food was short (only a day) as opposed to other studies in which the fish went through several days or even weeks of food deprivation. Similar results were observed by Rosauer et al. (2009) and Palma et al. (2010), who adopted five-day and two-day food restriction periods while working with walleye (Sander vitreus) fingerlings and juvenile tilapia, respectively. At the end of the experiment, the fish that were subjected to food restriction showed a final weight that was similar to those receiving continuous food. Therefore, this strategy can be adopted in the diet of these species without compromising their performance. Xiao et al. (2013), while working with juvenile black seabream (Acanthopagrus schlegelii), in addition to observing complete compensation in fish under food restriction for two days per week, also verified a weight gain/ performance that was superior to fish subjected to one day of food restriction per week, thereby providing evidence of growth overcompensation.

Studies of longer feed restriction cycles have been performed with different species; however, some researchers have shown that this practice does not favour compensatory growth. Negative results following weeks of fasting were observed by Ribeiro and Tsuzuki (2010) and Peres et al. (2011), while performing tests with juvenile snook (Centropomus parallelus Poey) and juvenile Sparus aurata, respectively. At the end of their experiments, the authors only observed partial compensatory growth in fish subjected to a maximum of two weeks of feed restriction.

Table 2. Productive performance parameters: final weight (FW), weight gain (WG), daily weight gain (DWG), feed consumption $\left(\mathrm{F}_{\text {cons }}\right.$ ), feed consumption (FC), daily feed consumption (DFC), feed conversion ( $\left.\mathrm{F}_{\text {conv }}\right)$, survival (SUR), fillet yield at $200 \mathrm{~g}$ (YFil1), final fillet yield (YFil2), protein efficiency ratio (PER) and protein retention rate (PRR) of Nile tilapia subjected to different feeding strategies.

\begin{tabular}{lrrrrrr}
\hline \multirow{2}{*}{ Variable } & \multicolumn{5}{c}{ Treatment } & CV $^{1}$ \\
\cline { 2 - 5 } & $\mathrm{C}$ & $\mathrm{R} 20$ & $\mathrm{R} 200$ & $\mathrm{R} 400$ & $\mathrm{R} 600$ & \\
\hline WF $\left(\mathrm{g} \mathrm{fish}^{-1}\right)$ & 1071,05 & 1002,60 & 1052,16 & 1019,93 & 1068,25 & 3,94 \\
${\mathrm{WG}\left(\mathrm{g} \mathrm{fish}^{-1}\right)}^{1047,50}$ & 979,05 & 1028,61 & 996,37 & 1044,70 & 7,05 \\
DWG $\left(\mathrm{g} \mathrm{day}^{-1}\right)$ & 4,03 & 3,77 & 3,96 & 3,83 & 4,02 & 4,03 \\
FC $\left(\mathrm{g} \mathrm{fish}^{-1}\right)$ & 1699,02 & 1528,58 & 1576,68 & 1564,36 & 1614,67 & 10,09 \\
DFC $\left(\mathrm{g} \mathrm{day}^{-1}\right)$ & 6,53 & 5,88 & 6,06 & 6,02 & 6,21 & 6,03 \\
$\mathrm{~F}_{\text {cons }}$ & 1,62 & 1,56 & 1,53 & 1,57 & 1,55 & 4,82 \\
SUR (\%) & 88,25 & 89,50 & 86,75 & 86,50 & 84,00 & 4,21 \\
YFil1 (\%) & 36,68 & 36,38 & 35,90 & 38,36 & 35,50 & 4,3 \\
YFil2 (\%) & 32,17 & 34,04 & 34,03 & 36,21 & 34,13 & 7,4 \\
PER (\%) & 21,34 & 21,71 & 22,77 & 22,26 & 23,30 & 5,4 \\
PPR (\%) & 16,90 & 17,62 & 18,60 & 17,76 & 18,12 & 4,4 \\
\hline
\end{tabular}

$\mathrm{CV}^{1}$ : coefficient of variation. 
The results for feed consumption previously reported for tilapia were not consistent with those of this study. Wang et al. (2009), while studying feed restriction with Nile tilapia, found that there was a higher consumption of feed by fish that went through restriction during the refeeding period; however, there were no observed changes in fish performance due to the higher food ingestion. However, Palma et al. (2010) reported a lower feed consumption by fish under feed restriction, which reached the same weight by the end of the experiment as those fish fed continuously. This discrepancy can be explained by the compensatory growth in fish, which is related to how long these fish were deprived of food. Thus, long periods of fasting, even if followed by refeeding and increased feed consumption, do not ensure that full compensatory growth is achieved (i.e., hyperphagia does not necessarily result in high efficiency feeding during compensatory growth).

For the carcass body components, the R20 treatment had the lowest value $(\mathrm{P}<0.05)$ for dry matter, which was not different from the control treatment. This in turn was not different from the other treatments, which had higher values for this variable (Table 3). The least ether extract content was observed in fish from the R20 treatment, with this figure being higher $(11.62 \%)$ than the values found in fish from the R400 treatment. Therefore, this showed the highest ether extract value, albeit with similar values to those observed in the control treatments, for the R200 and R600 treatments. Differences in the protein levels in the fish carcasses were also determined. The fillet composition during the first and second filleting was not significantly different $(\mathrm{P}>0.05)$ for the variables analysed, with the exception of gross energy from the first filleting, with R200 reflecting the best result, along with the R20, R400 and R600 treatments (Table 3). Zhu et al. (2005) and Wang et al. (2009) observed differences in the body composition of the fish during the refeeding phase; however, by the end of this period the body variables were similar to those of fish with no feeding restrictions. The different feed restriction strategies did not influence the fillet yield during either filleting; they also did not interfere with the protein retention rate or protein efficiency ratio regardless of when the feed restriction was initiated (Table 2). Wang et al. (2000) observed greater protein retention rates than those observed in this study by imposing a restriction lasting several weeks, with subsequent tilapia refeeding.

Table 3. Chemical-bromatological composition: dry matter (DM), mineral matter (MM), gross energy (GE), ether extract (EE) and crude protein (CP) of the carcasses and the fillets (F1 and F2) of Nile tilapia subjected to different feeding strategies ${ }^{(1)}$.

\begin{tabular}{|c|c|c|c|c|c|c|}
\hline & & \multicolumn{5}{|c|}{ Variable } \\
\hline & & $\mathrm{DM}$ & MM & GE & $\mathrm{EE}$ & $\mathrm{CP}$ \\
\hline & Initial sample & 27.50 & 4.51 & 1082 & 7.65 & 19.39 \\
\hline \multirow{6}{*}{ 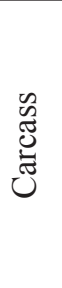 } & $\mathrm{C}$ & $27.80^{\mathrm{ab}}$ & $2.22^{\mathrm{ab}}$ & 1249 & $11.41^{\mathrm{ab}}$ & $21,94^{\mathrm{bc}}$ \\
\hline & R20 & $27.08^{b}$ & $2.16^{\mathrm{ab}}$ & 1244 & $10.32^{b}$ & $21,97^{\mathrm{ab}}$ \\
\hline & R200 & $29.11^{\mathrm{a}}$ & $2.38^{\mathrm{ab}}$ & 1318 & $12.14^{\mathrm{ab}}$ & $23,73^{\mathrm{a}}$ \\
\hline & R400 & $29.80^{\mathrm{a}}$ & $2.21^{\mathrm{b}}$ & 1377 & $12.85^{\mathrm{a}}$ & $23,70^{\mathrm{abc}}$ \\
\hline & $\mathrm{R} 600$ & $29.39^{\mathrm{a}}$ & $2.78^{\mathrm{a}}$ & 1313 & $11.94^{\mathrm{ab}}$ & $22,78^{\mathrm{c}}$ \\
\hline & $\mathrm{CV}^{2}(\%)$ & 3.20 & 9.11 & 2.11 & 4.25 & 1.44 \\
\hline
\end{tabular}




\begin{tabular}{|c|c|c|c|c|c|c|}
\hline \multirow{6}{*}{ 厌 } & $\mathrm{C}$ & 20.05 & 0.99 & $1021^{b}$ & 4.21 & 16,35 \\
\hline & R20 & 21.38 & 1.15 & $1117^{\mathrm{ab}}$ & 4.39 & 17,48 \\
\hline & R200 & 20.86 & 1.07 & $1140^{\mathrm{a}}$ & 4.67 & 16,91 \\
\hline & R400 & 20.32 & 0.93 & $1061^{\mathrm{ab}}$ & 4.16 & 16,49 \\
\hline & R600 & 20.59 & 1.11 & $1091^{\mathrm{ab}}$ & 4.29 & 16,30 \\
\hline & CV (\%) & 5.01 & 17.34 & 2.57 & 10.62 & 2.88 \\
\hline \multirow{6}{*}{$\sqrt{1}$} & $\mathrm{C}$ & 14.46 & 0.89 & 973 & 4.85 & 13,95 \\
\hline & R20 & 19.26 & 0.86 & 1049 & 4.96 & 14,44 \\
\hline & R200 & 17.37 & 0.82 & 948 & 4.95 & 12,62 \\
\hline & R400 & 16.72 & 0.87 & 892 & 4.61 & 12,53 \\
\hline & R600 & 17.22 & 0.83 & 931 & 4.46 & 12,55 \\
\hline & CV $(\%)$ & 9.77 & 9.52 & 2.39 & 10.22 & 4.43 \\
\hline
\end{tabular}

${ }^{(1)}$ Means followed by different letters in the columns differ significantly from each other, at a $5 \%$ level of probability, based on Tukey's test.

${ }^{(2)}$ Coefficient of variation.

The monthly biometrics analyses showed This decrease was due to the reduction in ambient differences in weight gain among the feeding temperature, which remained around $23.0 \pm 0.42$ strategies (Figure 1) throughout the experimental period, except in biometrics held at 60 days, in which a reduction in this parameter was observed.

${ }^{\circ} \mathrm{C}$ and compromised fish development. With the exception of the reduced growth observed during this biometric, there was an increased weight gain in fish in all the other biometrics.

Figure 1. Weight gain (WG) among the biometrics of Nile tilapia subjected to different feeding strategies ${ }^{(1)}$.

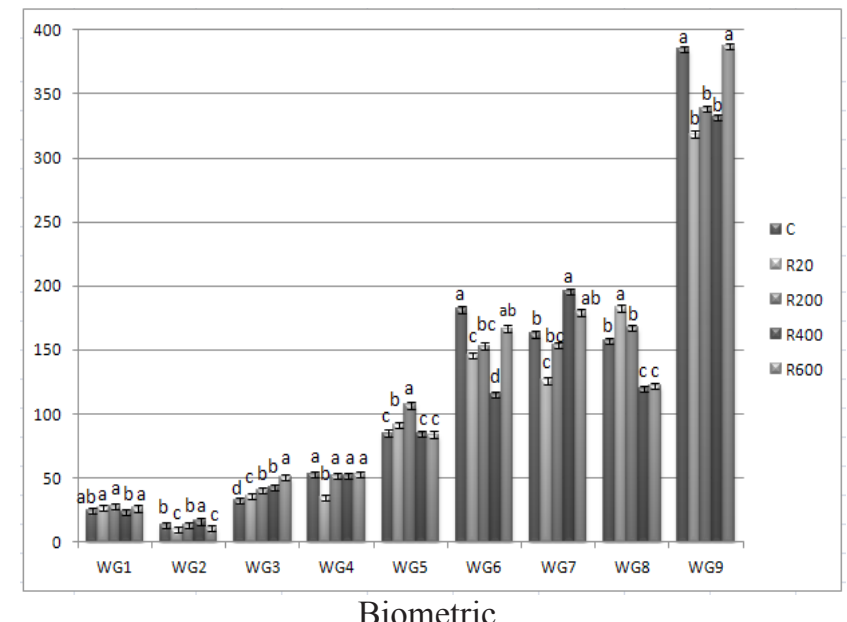

${ }^{(1)}$ Means followed by different letters in the columns differ significantly from each other, at a 5\% level of probability, based on Tukey's test. 
By means of economic analysis, the R20 treatment had the lowest variable production cost $\left(\mathrm{R} \$ \mathrm{~g}^{-1}\right)$ (Table 4) when compared with the other treatments (the control had the highest production cost). Therefore, adopting one fasting day per week for the whole cycle resulted in savings in variable production costs, based on the reduced amount of feed provided, in addition to the reduced labour costs. The largest saving in variable production costs is more easily observed by multiplying the total cost $\left(\mathrm{R} \$ \mathrm{~g}^{-1}\right)$ with a biomass value, which is more realistic in fish farming systems, (e.g., 1 ton). While developing a forecast based on this, the R20, R200, R400 and R600 treatments would provide savings of approximately $8.4,17.91,3.83$ and $3.65 \%$ in the total variable cost of production, when compared to the control treatment with savings of $\mathrm{R} \$ 980.00$, $\mathrm{R} \$ 210.00$ and $\mathrm{R} \$ 460.00 \mathrm{R} \$ 200.00$, respectively.

Table 4. Days worked, labour costs, feed costs, total variable cost (labour cost + feed cost) and cost of production of Nile tilapia fillets subjected to different strategies and feed.

\begin{tabular}{lccccc}
\hline \multirow{2}{*}{ Variable } & \multicolumn{5}{c}{ Treatment } \\
\cline { 2 - 6 } & $\mathrm{C}$ & $\mathrm{R} 20$ & $\mathrm{R} 200$ & $\mathrm{R} 400$ & $\mathrm{R} 600$ \\
\hline Days worked & 259 & 226 & 242 & 246 & 250 \\
Labour costs $\left(\mathrm{R} \$ \mathrm{~g}^{-1}\right)$ & 0.00282 & 0.00194 & 0.00250 & 0.00269 & 0.00274 \\
Feed costs $\left(\mathrm{R} \$ \mathrm{~g} \mathrm{~g}^{-1}\right)$ & 0.00264 & 0.00256 & 0.00251 & 0.00257 & 0.00253 \\
Total variable cost $\left(\mathrm{R} \$ \mathrm{~g}^{-1}\right)$ & 0.00547 & 0.00449 & 0.00501 & 0.00526 & 0.00527 \\
Variable prod cost - fillet $\left(\mathrm{R} \$ \mathrm{~g}^{-1}\right)$ & 4.376 & 3.592 & 4.008 & 4.208 & 4.216 \\
\hline
\end{tabular}

Studies by Abdel-Hakim et al. (2009) and Palma et al. (2010) also showed positive results while using feed restriction for fish management, presenting a reduction in feed costs without compromising performance, growth or muscle composition. This reduction in feed costs is relatively important because feed costs represent the major variable cost in aquaculture (SAMPAIO; BRAGA, 2005); consequently, producers have paid special attention to feed and feeding management (SCORVO FILHO et al., 2010). The lowest cost of fillet production was observed in the R20 treatment (Table 4), which was $18 \%$ cheaper to produce when compared with the control treatment fillet. In this way, the fillets from all the treatments were produced with the same feed, in the same time period, and had the same chemical-bromatological composition but with different variable production costs depending on the adopted feed management system.
Table 5 includes data regarding the biomass produced and the nitrogen balance at the end of the experiment. There was no significant difference in the amount of nitrogen supplied in the feed between the treatments, and there were no differences in the amount of nitrogen excreted between treatments. Despite the absence of any statistical differences regarding nitrogen elimination in the water bodies (in percentage terms), the R20 treatment made the least contribution to nitrogen metabolite elimination, with $21 \%$ less nitrogen excreted into the environment compared to the control treatment, which released more nitrogen compound. It is important to reduce the waste from fish farming because the leftover feed, faeces and waste from the metabolism play a role in increasing the nutrient concentration of fish farming water bodies (QUEIROZ; BOEIRA, 2007). This encourages the eutrophication process and the subsequent proliferation of plant organisms such as algae and 
aquatic plants (MALLASEN et al., 2008). When occurring at high levels, eutrophication leads to decreased water quality and may cause changes in the structure of aquatic communities, which in turn affects the balance of the ecosystem (FERREIRA et al., 2005). Therefore, using suitable feeding strategies can mitigate the amount of nutrients in the water bodies, which helps the quality of the water and effluents from fish farming (QUEIROZ; BOEIRA, 2007). Differences regarding the quantity of incorporated nitrogen were also not verified, however, there was no difference in the efficiency of the incorporated nitrogen. The control treatment showed the least incorporation efficiency at $35.11 \%$ less than that of the R200 treatment.

Table 5. Mean nitrogen supplied in the feed $(\mathrm{kg})$, biomass produced $\left(\mathrm{kg} \mathrm{m}^{3}\right)$, excreted nitrogen $(\mathrm{kg})$, incorporated nitrogen $(\%)$ and incorporated nitrogen efficiency $(\%)^{(1)}$ in the production of Nile tilapia subjected to different feeding strategies.

\begin{tabular}{lccccc}
\hline \multirow{2}{*}{\multicolumn{1}{c}{ Variable }} & \multicolumn{5}{c}{ Treatment } \\
\cline { 2 - 6 } & $\mathrm{C}$ & $\mathrm{R} 20$ & $\mathrm{R} 200$ & $\mathrm{R} 400$ & $\mathrm{R} 600$ \\
\hline Nitrogen supplied in the feed & 6.6 & 5.8 & 6.1 & 6.0 & 6.0 \\
Biomass produced & 92.35 & 87.55 & 89.18 & 86.19 & 87.79 \\
Incorporated nitrogen & 26.37 & 28.22 & 30.16 & 30.91 & 30.08 \\
Excreted nitrogen & 5.32 & 4.19 & 4.24 & 4.31 & 4.35 \\
Incorporated nitrogen efficiency & $19.57^{\mathrm{b}}$ & $28.22^{\mathrm{ab}}$ & $30.16^{\mathrm{a}}$ & $28.15^{\mathrm{ab}}$ & $27.67^{\mathrm{ab}}$ \\
\hline
\end{tabular}

${ }^{(1)}$ Means followed by different letters in the columns differ significantly from each other, at a $5 \%$ level of probability, based on Tukey's test.

\section{Conclusions}

A one-day per week feed restriction strategy can be adopted from the earliest stages of life without compromising the productive performance or body composition of Nile tilapia. A strategy that maintains fish at a food restriction level starting from 200 $\mathrm{g}$ promotes better efficiency for incorporating dietary nitrogen. In addition, a reduction in variable production costs can result from a reduction in feed and labour costs. For example, the smallest variable costs are incurred with a reduced working time when food restriction is implemented at the beginning of production with fish weighing $20 \mathrm{~g}$.

\section{Acknowledgements}

We thank the Fazendas Reunidas Vale do Juliana for making their facilities available for running the experiment and their employees for feeding assistance. We thank the Aguavale fish farm for supplying the fish and feed, the Coopecon for supplying their facilities and staff for the filleting and the Coordination for the improvement of Higher Education Personnel (Capes) for their financial support.

\section{References}

ABDEL-HAKIM, N. F.; ABO STATE, H. A.; ALAZAB, A. A.; EL-KHOLY, KH. F. Effect of feeding regimes on growth performance of juvenile hybrid tilapia (Oreochromis niloticus x Oreochromis aureus). World Journal of Agricultural Sciences, Dokkie, v. 5, n. 1, p. 49-54, 2009.

ALI, M.; NICIEZA, A.; WOOTTON, R. J. Compensatory growth in fishes: a response to growth depression. Fish and Fishiries, Oxford, v. 4, n. 2, p. 147-190, 2003.

ASSOCIATION OF OFFICIAL ANALYTICAL CHEMISTS - AOAC. Official methods of analysis. $17^{\text {th }}$ ed. Association of Official Analytical Chemists. Washington, DC: AOAC, 2000. 1410 p. 
BLANQUET, I.; OLIVA-TELES, A. Effect of feed restriction on the growth performance of turbot (Scophthalmus maximus L.) juveniles under commercial rearing conditions. Aquaculture Research, Oxford, v. 41, n. 8, p. 1255-1260, 2010.

CHERVINSKI, J. Environmental physiology of tilapias. In: PULLIN, R. V. S.; LOWE-MCCONNELL, R. H. (Ed.). The biology and culture of tilapias. Manila: International Centre for Living Aquatic Resources Management, 1982. p. 119-128.

DAVIES, O. A.; INKO-TARIAH, M. B.; AMACHREE, D. Growth response and survival of Heterobranchus longifilis fingerlings fed at different feeding frequencies. African Journal of Biotechnology, Nairobi, v. 5, n. 9, p. 778-780, 2006.

FERREIRA, R. A. R.; CAVENAGHI, A. L.; VALINI, E. D.; CORRÊA, M. R.; NEGRISOLI, E.; BRAVIN, L.F.N.; TRINDADE, M. L. B.; PADILHA, F. S. Monitoramento de fitoplâncton e microcistina no reservatório da UHE Americana. Planta Daninha, Viçosa, MG, v. 23, n. 2, p. 203-214, 2005.

FURUYA, W. M.; FUJII, K. M.; SANTOS, L. D.; SILVA, T. S. C.; SILVA, L. C. R.; SALES, P. J. P. Exigência de fósforo disponível para juvenis de tilápia-do-nilo. Revista Brasileira de Zootecnia, Viçosa, MG, v. 37, n. 9, p. 1517-1522, 2008.

GUIMARÃES, I. G.; MIRANDA, E. C.; RIBEIRO, V. L.; MARTINS, G. P.; MIRANDA, C. C. Farinha de camarão em dietas para tilápia do Nilo ("Oreochromis niloticus"). Revista Brasileira de Saúde e Produção Animal, Salvador, v. 9, n. 1, p. 140-149, 2008.

KUBITZA, F. Tilápia: tecnologia e planejamento na produção comercial. Jundiaí: Fernando Kubitza, 2000. $285 \mathrm{p}$.

MALLASEN, M.; BARROS, H. P.; YAMASHITA, E. Y. Produção de peixes em tanque rede e a qualidade da água. Revista Tecnologia \& Inovação Agropecuária, São Paulo, v. 1, n. 1, p. 47-51, 2008.

PALMA, E. H.; TAKAHASHI, L. S.; DIAS, L. T. S.; GIMBO, R. Y.; KOJIMA, J. T.; NICODEMO, D. Estratégia alimentar com ciclos de restrição e realimentação no desempenho produtivo de juvenis de tilápia-do-Nilo. Ciência Rural, Santa Maria, v. 40, n. 2, p. 421-426, 2010.

PERES, H.; SANTOS, S.; OLIVA-TELES, A. Lack of compensatory growth response in gilthead sea bream (Sparus aurata) juveniles following starvation and subsequent refeeding. Aquaculture, Amsterdam, v. 318, n. 3-4, p. 384-388, 2011.
QUEIROZ, J. F.; BOEIRA, R. C. Boas práticas de manejo (BPMs) para reduzir o acúmulo de amônia em viveiros de aquicultura. Jaguariúna: Empresa Brasileira de Pesquisa Agropecuária, 2007. 4 p. (Comunicado Técnico, 44).

$\mathrm{R}$ Development Core Team. $R$ : a language and environment for statistical computing. R. Foundation for Statistical Computing: Vienna, Austria, 2011.

RIBEIRO, F. F.; TSUZUKI, M. Y. Compensatory growth responses in juvenile fat snook, Centropomus parallelus Poey, following food deprivation. Aquaculture Research, Oxford, v. 41, n. 9, p. 226-233, 2010.

ROSAUER, D. R.; MORRIS, J. E.; CLAYTON, R. D. Role of compensatory growth in walleye fingerling production. North American Journal of Aquaculture, Bethesda, v. 71, n. 1, p. 35-38, 2009.

SAMPAIO, J. M. C.; BRAGA, L. G. T. Cultivo de tilápia em tanques-rede na barragem do Ribeirão de Saloméa - Floresta Azul - Bahia. Revista Brasileira de Saúde e Produção Animal, Salvador, v. 6, n. 2, p. 4252, 2005.

SCORVO FILHO, J. D.; FRASCÁ-SCORVO, C. M. D.; ALVES, J. M. C.; SOUZA, F. R. A. A tilapicultura e seus insumos, relações econômicas. Revista Brasileira de Zootecnia, Viçosa, MG, v. 39, p. 112-118, 2010. Suplemento Especial.

TACON, A. G. J.; FORSTER, I. P. Aquafeeds and the environment: policy implications. Aquaculture, Amsterdam, v. 226, n. 1-4, p. 181-189, 2003.

TIAN, X.; QIN, J. G. Effects of previous ration restriction on compensatory growth in barramundi Lates calcarifer. Aquaculture, Amsterdam, v. 235, n. 1-4, p. 273-283, 2004.

WANG, Y.; CUI, Y.; YANG, Y.; CAI, F. Compensatory growth in hybrid tilapia, Oreochromis mossambicus x $O$. niloticus, reared in seawater. Aquaculture, Amsterdam, v. 189, n. 1, p. 101-108, 2000.

WANG, Y.; LI, C.; QIN, J. G.; HAN, H. Cyclical feed deprivation and refeeding fails to enhance compensatory growth in Nile tilapia, Oreochromis niloticus L. Aquaculture Research, Oxford, v. 40, n. 2, p. 204-210, 2009.

XIAO, J. X.; ZHOU, F.; YIN, N.; ZHOU, J.; GAO, S.; LI, H.; SHAO, Q. J.; XU, J. Compensatory growth of juvenile black sea bream, Acanthopagrus schlegelli, with cyclical feed deprovation and refeeding. Aquaculture Research, Oxford, v. 44, n. 7, p. 10451057, 2013. 
ZHU, X.; XIE, S.; LEI, W.; CUI, Y.; YANG, Y.; WOOTTON, R. J. Compensatory growth in the Chinese longsnout catfish, Leiocassis longirostris following feed deprivation: Temporal patterns in growth, nutrient deposition, feed intake and body composition. Aquaculture, Amsterdam, v. 248, n. 1-4, p. 307-314, 2005. 
